\title{
Evaluasi Pengelolaan Sistem Informasi Administrasi pada Dinas Kependudukan dan Pencatatan Sipil Kota Tomohon
}

\author{
$1^{\text {st }}$ Jeane Mantiri \\ FIS UNIMA \\ Prodi ilmu administrasi negara \\ Tondano, Indonesia \\ jeanelihta@unima.ac.id \\ $2^{\text {nd }} A b d u l R$. Dilapanga \\ FIS UNIMA \\ Prodi ilmu administrasi negara \\ Tondano, Indonesia \\ abdulrahmandilapanga@unima. \\ ac.id \\ $3^{\text {rd }}$ Christo Mongi \\ FIS UNIMA \\ Prodi ilmu administrasi negara \\ Tondano, Indonesia \\ christomongi96@gmail.com
}

Abstrak- Penelitian ini bertujuan untuk mendeskripsi secara administrasi pengelolaan sistem informasi administrasi kependudukan pada Dinas Kependudukan Dan Pencatatan Sipil Kota Tomohon, dengan menggunakan pendekatan kualitatif, dan teknik pengumpulan data yaitu: observasi, dokumentasi, dan wawancara. Hasil penelitian menunjukkan bahwa secara umum evaluasi pengelolaan sistem informasi administrasi kependudukan pada Dinas Kependudukan dan Pencatatan Sipil Kota Tomohon dapat dikatakan efektif berdasar target capaian dokumen yakni: 1). Kartu Keluarga mencapai $89 \%$ sampai 91\%,2). KTP mencapai 92\% sampai 94\%, 3). Akta Kelahiran mencapai 70\% sampai 90\%, 4). Akta Kematian mencapai 42\% sampai 79\%, 5). Akta Perkawinan mencapai $53 \%$ sampai $79 \%$. Target capaian seharusnya $100 \%$, mengingat dokumen kependudukan dan pencatatan Sipil berhubungan dengan identitas penduduk yang harus jelas dan pasti. Untuk itu disarankan sebaiknya: pencapaian administrasi pengelolaan sistem informasi administrasi kependudukan pada Dinas Kependudukan dan Pencatatan Sipil yang berkaitan dengan lima dokumen yakni: 1). Kartu Keluarga, 2). KTP, 3). Akta Kelahiran 4). Akta Kematian, 5). Akta Perkawinan sebaiknya mencapai $100 \%$ untuk menjamin kepastian identitas penduduk dan warga negara sebagai dokumen negara.

Kata kunci : Evaluasi Pengelolaan Sistem Informasi Administrasi Kependudukan. 


\section{PENDAHULUAN}

Sistem Informasi Administrasi Kependudukan (SIAK) merupakan suatu sistem informasi berbasis web yang disusun berdasarkan prosedur-prosedur dan memakai standarisasi khusus yang bertujuan untuk menata Sistem Administrasi dibidang Pendaftaran Penduduk dan Pencatatan Sipil sehingga tercapai tertib Administrasi dan membantu bagi petugas dijajaran Pemerintah Daerah khususnya Dinas Kependudukan dan Pencatatan Sipil didalam menyelenggarakan layanan kependudukan dan Pencatatan Sipil.

Pengelolaan Sistem Informasi Administrasi Kependudukan daring diatur dalam Undang-Undang No. 24 Tahun 2013 Tentang perubahan atas Undang-Undang No. 23 Tahun 2006 tentang Administrasi Kependudukan [5]. Peraturan Menteri Dalam Negeri (Permendagri) No. 25 Tahun 2011 Tentang Pedoman Pengkajian, Pengembangan, dan Pengelolaan Sistem Informasi Administrasi Kependudukan, serta Peraturan Pemerintah No. 37 Tahun 2007 tentang pelaksanaan Undang-Undang No. 23 Tahun 2006 Tentang Administrasi Kependudukan [6].

Mengacu pada dasar hukum diatas maka Administrasi Kependudukan dalam pasal 1 ayat (1) adalah penataan dan penertiban dalam penertiban dokumen dan data kependudukan melalui pendaftaran penduduk, pencatatan sipil, pengelolaan sistem informasi administrasi kependudukan serta pendayagunaan hasilnya untuk pelayanan publik dan pembangunan sektor lain.

Pengelolaan Sistem Informasi Administrasi Kependudukan (SIAK), itu sangat dibutuhkan Standar Operasional Prosedur (SOP) dalam hal ini Mekanisme atau proses pembuatan dokumen kependudukan dan pencatatan sipil agar dokumen-dokumen kependudukan dan pencatatan sipil bisa Tertata dengan baik untuk meningkatkan pelayanan. Karena dalam pengurusan dokumen kependudukan dan pencatatan sipil itu harus lengkap dan terintegrasi dalam hal ini untuk pembangunan nasional. Sesuai dengan Peraturan Pemerintah Republik Indonesia Nomor 37 Tahun 2007 Tentang Pelaksanaan Undang-Undang No. 23 Tahun 2006 dan di rubah dalam UndangUndang No. 24 Tahun 2013 bahwa Pengelolaan Sistem Informasi Administrasi Kependudukan (SIAK) bertujuan untuk (1) Meningkatkan Kualitas Pelayanan Pendaftaran Penduduk dan Pencatatan Sipil (2) Menyediakan Data dan Informasi Skala Nasional dan Daerah untuk Mengelolah Database, Lengkap, Mutakhir serta Terintegrasi [5].

Tetapi berdasarkan observasi yang saya teliti ternyata dalam pengelolaan sistem informasi administrasi kependudukan pada dinas kependudukan dan pencatatan sipil Kota 
Tomohon, meskipun pemerintah daerah telah melaksanakan program tersebut dengan semaksimal mungkin, ternyata masih ada permasalahan yang di dapati dilapangan yaitu :

Pertama, sering terjadi NIK ganda (Duplicated Record) dalam pencetakan KTP dikarenakan masyarakat didapati sudah merekam dua kali sehingga KTP tersebut tidak bisa dicetak. Selain itu ketika akan melakukan transfer di Bank dan melakukan pendaftaran Kartu prabayar atau SIM Card KTPnya tidak terbaca dikarenakan belum di Aktivasi Kartu.

Kedua, didapati di Capil Tomohon seorang Ibu dan Bapak belum menikah tetapi sudah di satu Kartu Keluarga, selain itu banyak masyarakat Kota Tomohon yang belum memperbaharui kartu keluarga sehingga ketika akan mengurus dokumen lain seperti BPJS, PASPOR, Perijinan akan mengalami masalah,

Ketiga, akta Kelahiran yang sudah tidak menggunakan kelengkapannya dalam pengurusan dokumen tersebut.

Keempat, belum profesional dalam penegakan aturan yang ada di kantor, dan belum terlalu mahir dalam pengelolaan SIAK.

Kelima, sarana dan prasarana yang masih kurang memadai.

\section{Tujuan Penelitian}

Penelitian ini bertujuan untuk menggambarkan secara Administrasi Pengelolaan Sistem Informasi Administrasi Kependudukan pada Dinas Kependudukan dan Pencatatan Sipil Kota Tomohon

\section{METODE PENELITIAN}

Penelitian ini menggunakan pendekatan kualitatif bersifat deskriptif, yaitu berusaha mendapatkan informasi yang selengkap mungkin mengenai Evaluasi Pengelolaan Sistem Informasi Administrasi Kependudukan di Kota Tomohon, pada mekanisme pembuatan dokumen KK, KTP-El, Akta kelahiran, Akta Kematian dan Akta perkawinan.

\section{Fokus Penelitian}

Fokus penelitian ini yaitu Program Penataan Sistem Informasi Administrasi Kependudukan didalamnya terdapat kegiatankegiatan yang menunjang fasilitasi dan produksi dokumen Kependudukan dan Pencatatan Sipil, menyangkut Mekanisme atau Proses Pembuatan Dokumen KK, KTP-El, Akta Kelahiran, Akta Kematian, dan Akta Perkawinan.

\section{Teknik Analisis Data}

Teknik Analisis Data menurut Sugiyono (2012:89) analisis data adalah proses mencari dan menyusun data secara sistematis data yang diperoleh dari hasil wawancara, catatan lapangan dan dokumentasi, dengan cara 
mengorganisasikan data ke dalam kategori, menjabarkan ke dalam unit-unit, melakukan sintesa, menyusun ke dalam pola, memilih mana yang penting dan yang akan dipelajari, dan membuat kesimpulan sehingga mudah dipahami oleh diri sendiri maupun orang lain. Miles dan Huberman mengemukakan terdapat 3 langkah dalam analisis data, yaitu reduksi data, display data, dan verifikasi data [9].

\section{Reduksi Data}

Menurut Sugiyono (2012:92) mereduksi data berarti merangkum, memilih hal-hal yang pokok, memfokuskan pada hal-hal yang penting.

\section{Display Data}

Setelah data direduksi, maka langkah seharusnya dalam analisis analisis data ini adalah display data atau penyajian data. Miles dan Huberman menyatakan bahwa yang paling sering digunakan untuk menyajikan data dalam penelitian kualitatif adalah dengan teks yang bersifat naratif.

3. Verifikasi Data

Langkah ketiga dalam analisis data kualitatif adalah penarikan kesimpulan dan verifikasi.

\section{HASIL DAN PEMBAHASAN}

\section{Mekanisme Pembuatan Dokumen Kartu}

\section{Keluarga}

Proses dan mekanisme pembuatan KK belum sesuai dengan SOP (Standar Opreasional Prosedur) karena pembuatan KK tidak sesuai dengan waktu yang sudah di tentukan dalam
SOP. Hal diakibatkan karena kurang menunjangnya fasilitas pembuatan dokumen KK seperti alat printer, mesin fotocopy sering rusak, ribbon (tinta) habis dan jaringan internet serta kelengkapan berkas dari masyarakat yang ingin membuat KK tidak sesuai dengan syarat yang ditentukan dan data-datanya beda-beda selain itu didapati juga ternyata masyarakat belum mengambil surat pindah melainkan masih terdaftar ke daerah asalnya, terutama tidak ada akta sehingga proses pembuatan dokumen KK terhambat selain itu yang harus menandatangani dokumen KK sering tidak berada ditempat dalam hal ini adalah kepala dinas dan terutama target capaian Kartu Keluarga belum mencapai $100 \%$.

\section{Mekanisme Pembuatan KTP-EL}

Prosedur Pembuatan belum sesuai dengan prosedur menyangkut langkah-langkah pembuatannya dari menyampaikan permohonan sampai dengan pencetakannya. Hal ini karenakan masyarakat yang sering kali tidak melengkapi berkas dan dalam datanya setelah diverifikasi ternyata menimbulkan Duplicated Record atau memiliki NIK yang ganda karena sudah pernah merekam 2 kali sehingga tidak bisa mencetak KTP, dan fasilitas dalam kantor berupa printer yang sering kehabisan ribbon (tinta) juga gangguan pada jaringan sehingga tidak sesuai dengan prosedur yang telah ditentukan dan terutama target capaian KTP-EL belum mencapai $100 \%$. 


\section{Mekanisme Pembuatan Dokumen Akta}

\section{Kelahiran}

Prosedur Pembuatan belum sesuai dengan prosedur menyangkut langkah-langkah pembuatan mulai dari permohonan sampai penandatanganan. Hal ini karenakan masyarakat yang sering kali tidak melengkapi berkas dan setelah diverifikasi dalam datanya ternyata sering didapati masyarakat yang akan membuat akta kelahiran, telah menikah yang bisa dibilang sudah berumur dan seringkali mereka tidak membuat akta perkawinan dan surat nikah dari gereja, dalam hal ini itu adalah salah satu syarat untuk prmbuatan akta kelahiran, selain itu sering ada gangguan jaringan dalam pencetakan dokumen Akta kelahiran, mesin fotocopy yang rusak serta yang akan menandatangani dokumen tidak berada di tempat yaitu kepala dinas, dalam hal ini dalam prsedur pembuatan akta kelahiran tidak sesuai dengan prosedur yang diterapkan yaitu menyangkut juga waktunya dan terutama target capaian pembuatan Akta Kelahiran belum mencapai $100 \%$.

\section{Mekanisme Pembuatan Dokumen Akta}

\section{Kematian}

Prosedur Pembuatan belum sesuai dengan prosedur menyangkut langkahlangkanya yaitu menyampaikan permohonan sampai dengan penandatanganannya. Hal ini karenakan masyarakat yang sering kali tidak melengkapi berkas dan ketika diverifikasi ternyata masyarakat tidak mencantumkan atau lupa mencantumkan siapa yang meninggal karena dalam pembuatan akta kematian itu harus dicantumkan siapa yang meninggal, selain itu kendala yang sering terjadi ketika orang yang meninggal ternyata belum terdaftar sebagai penduduk kota tomohon otomatis tidak bisa diterbitkan karena persyaratan yang ditentukan harus terdaftar di kota tersebut serta gangguan jaringan dan mesin fotocopy yang rusak tentunya yang terhambat proses pembuatan sehingga prosedur tidak berjalan sesuai waktu yang ditentukan serta jaringan yang sering terjadi gangguan dan ketika dalam menandatangani dokumen kepala dinas tidak ada di tempat dalam hal ini prosedur tidak berjalan sesuai waktu yang ditentukan.

\section{Mekanisme Pembuatan Akta Perkawinan}

Prosedur pembuatan Belum sesuai dengan prosedur menyangkut langkahlangkanya dari pemohonan sampai tanda tangan. Hal ini karenakan masyarakat yang sering kali tidak melengkapi berkas selanjutnya dalam meneliti memeriksa persyaratan pencatatan perkawinan kendala yang terjadi jika pasangan terdaftar didaerah lain dalam hal ini pernah tinggal di daerah lain otomatis akan diberikan penunggalan data yang mana salah satu data di kota yang sebelumnya ditempati harus di hapus, ketika diverifikasi waktu dalam prsedur yang diterapkan tidak sesuai dengan waktu yang ditentukan, selain itu tentunya jaringan yang terganggu, mesin fotocopy yang rusak dan tanda 
tangan kadis, jika kadis tidak di tempat otomatis dalam hal ini prosedur tidak sesuai tujuan.

Berdasarkan hasil penelitian yang diperoleh dilokasi penelitian didapati bahwa prosedur pelayanan dokumen Kependudukan dan Pencatatan Sipil tidak seperti yang diharapkan. Hal ini disebabkan karena masyarakat sering tidak melengkapi berkas yang ditentukan dalam Standar Oprasional Prosedur, data-data yang sering terjadi masalah, jaringan yang sering terganggu, alat pembuatan dokumen yang sering rusak atau kehabisan tinta serta pejabat yang akan menandatangani dokumen kependudukan dan pencatatan sipil tidak berada di tempat.

Mekanisme pembuatan dokumen Kependudukan dan Pencatatan Sipil. berdasarkan hasil penelitian yang dilakukan ternyata standar operasional prosedur yang diterapkan belum sesuai. Pengelolaan merupakan ilmu manajemen yang berhubungan dengan proses mengurus dan menangani sesuatu untuk mewujudkan tujuan tertentu yang ingin dicapai (Nugroho 2003 : 119) [8]. Dalam hal ini pengelolaan dokumen kependudukan dan pencatatan sipil untuk mewujudkan pelayanan yang baik kepada masyarakat. Pada kenyataannya pelayanan dan pengelolaan sesuai dengan apa yang didapati peneliti pada lokasi penelitian belum sesuai dengan standar yang ditetapkan hal ini dikarenakan kurang lengkapnya fasilitas yang ada menurut UnsurUnsur Manajemen menurut George R. Terry dalam bukunya principle of management yang diambil salah satunya adalah Machines (Peralatan Mesin) Untuk mengolah bahan baku menjadi barang jadi dibutuhkan seperangkat mesin dan peralatan kerja. Dengan adanya mesin maka waktu yang dibutuhkan dalam proses produksi akan semakin cepat dan efisien. Oleh karena itu dibutuhkan sumber daya yang handal dan bahan baku yang berkualitas untuk memperoleh hasil yang maksimal. Sering didapati juga dalam pembuatan kartu keluarga banyak masyarakat yang ketika akan membuat dokumen kependudukan dan pencatatan sipil ternyata data-data nya masih bermasalah. Menurut Mubyarto (dalam Ndraha, 1990 : 105) tentang partisipasi masyarakat yang mengemukakan bahwa partisipasi masyarakat adalah ketersediaan masyarakat untuk membantu berhasilnya setiap program sesuai kemampuan masyarakat tanpa mengorbankan kepentingan setiap individu. Kemudian dalam sumber daya manusia berdasarkan pada kenyataannya terdapat pegawai yang sering datang terlambat atau seringkali pegawai tidak balik ke kantor dalam hal ini prosedur yang diterapkan tentunya tidak sesuai dengan apa yang ditentukan karena dalam prosedur tentunya haris ada sumber daya manusia yang mengerjakan pekerjaan tersebut menurut UnsurUnsur Manajemen menurut George R. Terry dalam bukunya principle of management yang 
diambil salah satunya adalah Man ( Sumber Daya Manusia) Unsur manajemen yang paling vital adalah sumber daya manusia. Manusia membuat perencanaan dan mereka pula yang melakukan proses untuk mencapai tujuan tersebut. tanpa adanya sumber daya manusia maka tidak ada proses kerja, sebab pada prinsip dasarnya mereka adalah mahkluk pekerja.

Berdasarkan Hasil Penelitian yang diperoleh maka dalam capaian pembuatan dokumen Kartu Keluarga sudah hampir mencapai Target yang ditentukan yaitu pada Tahun 2016 yaitu 27.129 Keluarga dari 30.346 Keluarga yang terdata dan mencapai $89.40 \%$ sampai 91.01\% , pada Tahun 2017 yaitu 27.051 Keluarga dari 30.254 Keluarga terdata dan mencapai $67.33 \%$ sampai $91.33 \%$, dan pada Tahun 2018 yaitu 27.553 Keluarga dari 30.603 Keluarga yang terdata mencapai $88.11 \%$ sampai 91.50\% dan dapat dikatakan itu sudah Efektif. Menurut Sondang dalam Othenk (2008:4) Efektivitas menunjukkan keberhasilan dari segi tercapai tidaknya sasaran yang telah ditetapkan. Jika hasil kegiatan semakin mendekati sasaran, berarti makin tinggi Efektivitasnya.

Berdasarkan Hasil Penelitian yang diperoleh maka dalam capaian pembuatan dokumen KTP-EL sudah hampir mencapai Target yang ditentukan yaitu pada Tahun 2016 yaitu 64.422 jiwa wajib KTP-EL dan mencapai $89.92 \%$ sampai $84.13 \%$, pada Tahun 2017 yaitu
67.605 jiwa wajib KTP-EL dan mencapai 91.76\% sampai 94.84\%, dan pada Tahun 2018 yaitu 74.557 jiwa wajib KLTP-EL dan mencapai 92.93\% sampai $106.11 \%$ dan dapat dikatakan itu sudah Efektif. Yang secara sadar ditetapkan sebelumnnya untuk menghasilkan sejumlah pekerjaan tepat pada waktunya. Menurut Abdurahmat dalam Othenk (2008:7), Efektivitas adalah pemanfaatan sumber daya, sarana dan prasarana dalam jumlah tertentu yang secara sadar ditetapkan sebelumnnya untuk menghasilkan sejumlah pekerjaan tepat pada waktunya. Dapat disimpulkan bahwa Efektivitas berkaitan dengan terlaksanannya semua tugas pokok, tercapainya tujuan, ketetapan waktu, dan partisipasi aktif dari anggota serta merupakan keterkaitan antara tujuan dan hasil yang ditanyakan, dan menunjukkan derajat kesesuaian antara tujuan yang dinyatakan dengan hasil yang dicapai.

Berdasarkan Hasil Penelitian Capaian pembuatan dokumen Akta Kelahiran sudah bisa dikatakan sudah efektif karena mencapai Target yang ditentukan yaitu pada Tahun 2016 yang memiliki Akta Kelahiran sebesar 44.19\% dan yang belum memiliki Akta Kelahiran sebanyak 55.81\%, pada Tahun 2017 yang memiliki Akta Kelahiran sebesar 44.61\% dan yang belum memiliki Akta Kelahiran sebanyak $55.39 \%$, dan pada Tahun 2018 yang memiliki Akta Kelahiran sebesar $94.219 \%$ dan yang belum memiliki Akta Kelahiran sebanyak 
$3.250 \%$ menarik dilihat bahwa umur 0-19 Tahun memiliki persentase di atas $70 \%$ bahkan umur 0 9 Tahun memiliki Persentase di atas 90\%. Menurut Siagaan, (2001:24) Efektivitas pada dasarnya menunjukkan pada taraf tercapainya hasil, sering atau senantiasa dikaitkan dengan menekankan pada hasil yang dicapai selain itu dapat melihat pada bagaimana cara mencapai hasil yang dicapai itu dengan membandingkan antara input dan outputnya.

Penerbitan Akta Kematian sesuai data, belum menjadi gambaran jumlah penduduk yang telah meninggal di tahun tersebut, dikarenakan rata-rata yang membuat Akta Kematiab disebabkan adanya kepentingan yang mengikat dengan dokumen tersebut. Pada tahun 2016 sebesar 506 atau 42.16\%, tahun 2017 sebesar 776 atau $64.66 \%$, dan pada tahun 2018 sebesar 24.053 atau 79.50\%. Menurut Kurniawan (2016) Efektivitas merupakan kemampuan melaksanakan tugas dari pada suatu organisasiatau sejenisnya yang tidak adanya tekanan atau ketegangan diantara pelaksanaannya dalam mencapai tujuan yang telah ditetapkan.
Penerbitan dokumen Akta Perkawinan hanya diberikan kepada masyarakat non muslim, sedangkan masyarakat muslim menggunaka buku nikah, karena perbedaan tersebut maka jumlah penduduk yang memiliki akta perkawinan sangat sedikit karena belum ada kerjasama antara kementrian agama di masingmasing kabupaten/kota. Pada tahun 2016 sebesar 643 atau 53.58\%, pada tahun 2017 sebesar 650 atau $54.16 \%$, dan pada tahun 2018 sebesar 24.053 atau $79.50 \%$.

\section{PENUTUP}

\section{Kesimpulan}

Secara umum evaluasi pengelolaan sistem informasi administrasi kependudukan pada Dinas Kependudukan dan Pencatatan Sipil Kota Tomohon dapat dikatakan efektif berdasar target capaian dokumen yakni: 1). Kartu Keluarga mencapai 89\% sampai 91\%, 2). KTP mencapai 92\% sampai 94\%, 3). Akta Kelahiran mencapai 70\% sampai 90\%, 4). Akta Kematian mencapai $42 \%$ sampai $79 \%$, 5). Akta Perkawinan mencapai 53\% sampai 79\%. Target capaian seharusnya $100 \%$, mengingat dokumen kependudukan dan pencatatan Sipil berhubungan dengan identitas penduduk yang harus jelas dan pasti. 


\section{Saran}

Pencapaian administrasi pengelolaan sistem informasi administrasi kependudukan pada Dinas Kependudukan dan Pencatatan Sipil yang berkaitan dengan lima dokumen yakni: 1). Kartu Keluarga, 2). KTP, 3). Akta Kelahiran 4). Akta Kematian, 5). Akta Perkawinan sebaiknya mencapai $100 \%$ untuk menjamin kepastian identitas penduduk dan warga negara sebagai dokumen negara.

\section{UCAPAN TERIMA KASIH}

Terimakasih disampaikan kepada semua pihak yang boleh membanti dalam pelaksaan penelitian sehingga artikel ini dapat diselesaikan. 


\section{REFERENSI}

[1] Abdul Rahman Dilapanga, (2016), EvaluasiWajib Belajar Pendidikan Dasar, Manado: Yayasan Makaria Waya.

[2] Nanang Fattah, (2004). Konsep Manajemen Berbasis Sekolah (MBS) dan dewan sekolah. Bandung: Bani quraisy.

[3] Arkinto S. Jabar, C (2010), Evaluasi Program, Jakarta : Bumi Aksara

[4] Abdul Wahab, Solichin. 1997. Evaluasi Kebijakan Publik. Penerbit FIA UNIBRAW dan IKIP MALANG.

[5] Undang-Undang Republik Indonesia Nomor 24 Tahun 2013 Tentang Perubahan Atas Undang-Undang Nomor 23 Tahun 2006 Tentang Administrasi Kependudukan

[6] Peraturan Menteri Dalam Negeri Nomor 25 Tahun 2011 Tentang Pedoman Pengkajian, Pengembangan Dan Pengelolaan Sistem Informasi Administrasi Kependudukan.

[7] Peraturan Pemerintah Nomor 37 Tahun 2007 Tentang Pelaksanaan Undang-Undang Nomor 23 Tahun 2006 Tentang Administrasi Kependudukan.

[8] Nugroho. 2003. Kebijakan Publik Formulasi, Implementasi dan Evaluasi. Jakarta PT. Elex Media Komputindo.

[9] Sugiyono. 2012. Metode Penelitian Kuantitatif Kualitatif dan R\&D. Bandung: Alfabeta. 